\title{
Mario Botero García, Les Rois dans le «Tristan en prose». (Ré)écritures du personnage arthurien
}

\section{G. Matteo Roccati}

\section{(2) OpenEdition}

10 Journals

\section{Édition électronique}

URL : http://journals.openedition.org/studifrancesi/2064

DOI : 10.4000/studifrancesi.2064

ISSN : 2421-5856

Éditeur

Rosenberg \& Sellier

\section{Édition imprimée}

Date de publication : 1 avril 2014

Pagination : 118

ISSN : 0039-2944

\section{Référence électronique}

G. Matteo Roccati, « Mario Botero García, Les Rois dans le «Tristan en prose». (Ré)écritures du personnage arthurien », Studi Francesi [En ligne], 172 (LVIII | I) | 2014, mis en ligne le 01 avril 2014 consulté le 18 septembre 2020. URL : http://journals.openedition.org/studifrancesi/2064 ; DOI : https://doi.org/10.4000/studifrancesi.2064

Ce document a été généré automatiquement le 18 septembre 2020.

\section{(c)}

Studi Francesi è distribuita con Licenza Creative Commons Attribuzione - Non commerciale - Non opere derivate 4.0 Internazionale. 


\title{
Mario Botero García, Les Rois dans le «Tristan en prose». (Ré)écritures du personnage arthurien
}

\author{
G. Matteo Roccati
}

\section{RÉFÉRENCE}

MARIO BOTERO GARCÍA, Les Rois dans le «Tristan en prose». (Ré)écritures du personnage arthurien, Paris, Honoré Champion, 2011 («Essais sur le Moyen Age», 51), pp. 464.

«La figure royale dans la version en prose du Tristan, dans sa diversité, est avant tout conçue comme un personnage littéraire, comme une création au service d'une intrigue et qui n'a guère à voir avec une quelconque réalité historique» (p. 16). Après un examen des signes distinctifs et des fonctions de la royauté, l'étude des nouvelles figures royales et de l'évolution que les anciennes connaissent par rapport aux textes en vers, à la tradition arthurienne et aux chroniques «historiques», permet à l'A. d'expliciter leur rôle dans l'économie du roman: agencement des différents univers, valeurs chevaleresques illustrées par la royauté, modèles emblématiques et contradictoires constitués par Arthur et Marc. En toile de fond la problématique qui lie et oppose exercice du pouvoir et chevalerie: la figure du roi et celle du chevalier errant, a priori antinomiques, se rejoignent ici dans une conception idéalisée. La bibliographie et l' Index des personnages et auteurs médiévaux terminent le volume. 